\title{
Phonosemantic Interference: Multiple Motivation in the Imitative Word Coinage (on the Material of Invented Languages)
}

\author{
Varvara A. Davydova ${ }^{凶}$ \\ Saint Petersburg Electrotechnical University, St Petersburg, Russia

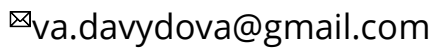

Introduction. Phonosemantic interference is a phenomenon in imitative word coinage in which the sound shape of a single imitative sign can be conditioned by several categorically different motives of nomination. Several phonosemantic studies have reported this effect; however, a clear definition of the term, the description of the existing models of motive combinations, as well as possible explanations behind this phenomenon have yet to be developed. The objective of this article is to attempt to formulate the definition of this term and to describe the mechanisms of phonosemantic interference using new linguistic material (artificially constructed lexis).

Methodology and sources. The study is conducted within the framework of the phonosemantic approach developed by Stanislav Voronin on the material of artificially constructed words from well-known fictional languages Lapin, Klingon, Elvish, and Navi. Methods of the research include the method of continuous sampling, typological comparison, and the method of phonosemantic analysis.

Results and discussion. Using the material of artificially constructed lexis, the examples of the combination of several motives of nomination for a single sound-imitative sign are demonstrated and the motives of their coinage are studied. The typological comparison of the artificially constructed words against imitative words of natural origin has revealed similar models of multiple motivation both in artificial and natural word coinage, which suggests that multiple nomination is a regular way of primary nomination. The definition of the term phonosemantic interference has been provided.

Conclusion. Multiple motivation reflects the complex nature of the intermodal perception of extralinguistic objects. In the case of phonosemantic interference, the phonetic form of a word is the product of a co-operative action of several senses. The reflection of several denotata in a single sound form increases the variety of primary forms and meanings and helps explicate subtle semantic contrasts. The notion of phonosemantic interference enables analyzing, describing, and understanding the mechanisms of complicated cases of imitative word coinage within the framework of the already well established phonosemantic taxonomy.

Key words: phonosemantics, onomatopoeia, sound symbolism, phonosemantic interference, denotatum, motivation, fictional languages.

For citation: Davydova V. A. Phonosemantic Interference: Multiple Motivation in the Imitative Word Coinage (on the Material of Invented Languages). DISCOURSE. 2020, vol. 6, no. 4, pp. 150-164. DOI: 10.32603/2412-8562-2020-6-4-150-164

Conflict of interest. No conflicts of interest related to this publication were reported.

Received 17.06.2020; adopted after review 08.07.2020; published online 26.10.2020

(c) Davydova V. A., 2020

Контент доступен по лицензии Creative Commons Attribution 4.0 License.

This work is licensed under a Creative Commons Attribution 4.0 License.

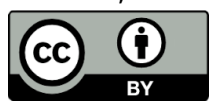




\title{
Фоносемантическая интерференция: множественная номинация в звукоизобразительном словообразовании
} (на материале вымышленных языков)

\author{
В. А. Давыдова ${ }^{凶}$ \\ Санкт-Петербургский государственный электротехнический университет «ЛЭтИ» \\ им. В. И. Ульянова (Ленина), Санкт-Петербург, Россия \\ 凶va.davydova@gmail.com
}

\begin{abstract}
Введение. Фоносемантическая интерференция - это явление из области примарного звукоизобразительного словообразования, при котором звуковая форма одного звукоизобразительного знака может определяться несколькими категориально разными мотивами номинации. Данный эффект был зарегистрирован в нескольких исследованиях из области фоносемантики. Тем не менее до сих пор осутствуют четкое определение самого понятия и описание существующих моделей сочетания мотивов номинации, а также возможных причин описанного феномена. Целью настоящей статьи является попытка сформулировать определение термина и описать механизмы фоносемантической интерференции, используя новый языковой материал (искусственно сконструированную лексику).
\end{abstract}

Методология и источники. Исследование проведено в русле фоносемантического подхода на материале хорошо известных вымышленных языков - лэпина, клингона, эльфийского и нави. В качестве методов исследования были использованы метод сплошной выборки, метод типологического сравнения и метод фоносемантического анализа.

Результаты и обсуждение. На материале искусственно сконструированной лексики в статье приводятся примеры сочетания нескольких мотивов номинации для одного звукоизобразительного языкового знака и рассматриваются сами мотивы номинации. Типологическое стравнение искусственно сконструированных слов с звукоизобразительными словами из естественных языков позволило обнаружить сходные модели в искусственном и естественном словообразовании, что позволяет считать множественную номинацию регулярным способом примарной номинации. В статье также предложено определение термина «фоносемантическая интерференция».

Заключение. Множественность мотивов номинации отражает сложную природу интермодального восприятия экстралингвистических объектов. В случае фоносемантической интерференции фонетическая форма слова формируется как результат взаимодействия нескольких источников ощущений. Отражение нескольких денотатов в одном звукоизобразительном знаке увеличивает разнообразие примарных форм и значений слова и позволяет выразить тонкие семантические контрасты. Понятие фоносемантической интерференции позволяет анализировать, описывать и глубже понимать механизмы сложных случаев звукоизобразительного словообразования, не меняя уже существующую хорошо зарекомендовавшую себя фоносемантическую таксономию.

Ключевые слова: фоносемантика, ономатопея, звукосимволизм, фоносемантическая интерференция, денотат, мотивация, вымышленные языки.

Для цитирования: Давыдова В. А. Фоносемантическая интерференция: множественная номинация в звукоизобразительном словообразовании (на материале вымышленных языков) // ДИСКУРС. 2020. Т. 6, № 4. С. 150-164. DOI: 10.32603/2412-8562-2020-6-4-150-164

Конфликт интересов. О конфликте интересов, связанном с данной публикацией, не сообщалось.

Поступила 17.06.2020; принята после рецензирования 08.07.2020; опубликована онлайн 26.10.2020 
Introduction. Words of sound-imitative origin are defined in linguistics as non-arbitrary motivated signs whose phonetic shape reflects of the (material) objects that those words designate. Numerous studies in the area of sound symbolism describe the tendencies and mechanisms of the link between the word and its object [1-13]. Nevertheless, this field still needs further investigation.

In this paper I describe a special type of imitative word coinage within the framework of the phonosemantic theory. The foundation of this theory and new research branch of phonosemantics was established by Stanislav Voronin in 1982 when he published his Ph.D. thesis "Fundamentals of Phonosemantics" [14].

The phonosemantic theory suggests a systemic approach to the problem of motivation. The whole array of imitative words is considered a single sound-imitative system of the language with several domains and, correspondingly, several modes of motivation. To add complexity to the problem, Voronin noticed a phenomenon of overlapping of several motives in one imitative sign. To describe this phenomenon of mixed or multiple motivation, S. V. Voronin coined the term phonosemantic interference [15, p. 48]. However, by doing so he only outlined this phenomenon on just few explanation leaving room for further research. Until now, the combination of several motives in primary nomination has gained little attention in phonosemantic studies. The objective of this article is to attempt to formulate the definition of this term and to describe the mechanisms of phonosemantic interference using new linguistic material (artificially constructed lexis).

Methodology and sources. The present research was conducted on the material of artificially constructed words from fictional languages. This choice was dictated by the following reasons:

(1) Natural words in language undergo different stages of their diachronic history [16]. This means that both their primary meaning and the original form, due to diachronic changes, can be obscured [14, p. 122-129]. In the area of natural lexis, the search for precise primary imitative forms is always a quest. On the opposite, the constructed words of fictional languages have an unchanged primary form, and for this reason, they are a useful material for the study of motivation.

(2) Previous studies of fictional languages have revealed that artificially constructed words can demonstrate non-arbitrary sound-sense correlations similar to the natural ones $[17,18]$.

(3) A study of subtle variants of motivation can be more successful with the use of highly variable material [19, p. 167]. Artificially constructed words fully comply with this requirement.

The lexical material for the research was obtained from the lexicons of well-known fictional languages, which could provide a representative number of words to analyze. For this purpose, I used the existing dictionaries of Lapin, Klingon, Elvish, and Navi [20-23].

Fictional words with sound-imitative properties were extracted from the dictionaries by the method of continuous sampling. Out of total of 4283 invented words, 394 demonstrated soundimitative properties.

The imitative status of these words was confirmed with the use of the method of phonosemantic analysis developed by S. V. Voronin [24]. This method allows for revealing the possible imitative status of a single word based on the data collected from etymological, extralinguistic, and interlinguistic sources. 
To verify my findings, I used the method of typological comparison against the lexical material from natural languages (preferably with confirmed sound-imitative status, such as [25]). In result, similar models of multiple motivation were found both in artificial and natural word coinage.

\section{Imitative word coinage.}

According to phonosemantic approach, the central unit of the imitative word coinage is the denotatum [14]. It is the mediator between the linguistic sign and extralinguistic reality. The denotatum is subjective; it is a psychophysiological product of the perception and mental processing of extralinguistic phenomena. Constant and essential features of the denoted object lay the basis for motivation [26, p. 106, 113]. The process of imitative word coinage can be briefly described in the following way. The objective parameters of an extralinguistic phenomenon transform into a subjective psychophysiological reflection of an object [14, p. 39], which is further imitated using the speech apparatus.

To illustrate the above, let us consider the following example. A constant and essential feature of the process of water ingestion is the act of swallowing with the tongue's movement. This extralinguistic event lays the basis for the motive of nomination. On the level of the physiological reflection, the muscular sensation of the stretched tongue produces a psychophysiological image of water swallowing - the denotatum. On the pre-linguistic level of imitation, it is rendered by a non-phonemic imitative gesture by means of speech organs [16, 27, 28]. In case of swallowing, such gesture is a tongue's movement imitating water-sucking - the kineme of swallowing. Finally, on the linguistic level, this gesture is approximated by the phonemes of a specific language. In my example, the muscular sensation in the flexible front part of the tongue is resembled by the articulation of coronal consonants, with the resulting imitative words like English slurp,suck,swig,sozzle, Russian cepбamb [s'orbat'] 'to drink', and German saugen 'to suck'.

\section{The phonosemantic classification.}

Before discussing the examples of the interference of motives in imitative coinage, it is necessary to understand what are the basic classes (types) of such motives. For this reason, I provide a brief overview of the phonosemantic taxonomy as it was developed by Voronin.

The whole edifice of the phonosemantic classification is based on the premise of the existing relationship between language and extralinguistic reality via the denotatum. The denotata, however, belong to different domains of the sound-imitative system and essentially differ in their relations with the referent (the designated object).

1. Acoustic denotata (onomatopoeia). The phonosemantic theory has switched the main focus of attention from the acoustic parameters of an extralinguistic object to the psychoacoustic parameters of an image perceived (the denotatum). Based on a psychoacoustic classification of the sound denotata, S. V. Voronin has developed the Universal Classification of Onomatopes (for details see $[29 ; 30$, p. 30-38; 14, p. 39-70]).

The whole edifice of the Classification is built on 3 basic parameters of sound denotata as they are perceived by the human ear: A. Pulse (an instant sound), B. Non-Pulse (durative tonal sound or durative noise), and C. Dissonance (a rapid series of pulses). The combination of these parameters describes the whole variety of sounds designated by the onomatopoeic words. The corresponding classes of onomatopes are: 
I. Instants - sounds perceived as instantaneous events such as English clap, plop, tick.

II. Continuants - sounds perceived as continuous noise or continuous tone: English hiss, swish, hoot, choo-choo.

III. Frequentatives - sounds perceived as harsh, raucous, vibrating sounds: English ripple, chirp, scrab.

There are also two hyper-classes of words in the Classification denotingcombinations of the first three parameters.

IV. Instants-continuants - pulses with lasting effects, such as English whang, bump, twang;

V. Frequentatives-Instants-Continuants - series of pulses with additional instant or continuous sound effects, such as English krash, flirt.

2. Non-acoustic denotata. This category encompasses all kinds of non-sound phenomena within the sphere of human perception. All non-acoustic denotata are multimodal, which means that non-sound facts of reality perceived through vision, smell, taste, or tactile sensations are iconically rendered in speech in a sound form. This poses the question about the intermediary, or a common denominator, which could make it possible to match events belonging to different modalities. Following the studies in the area of psychophysiology and psycholinguistics [31-33], Voronin suggested that it is the motor control system, or kinesthesis, that serves as a common ground and enables the transfer of information between sensory, emotive, and motor domains.

On the psychophysiological level, the perception and further processing of non-sound facts of reality always come with specific muscular movements including the muscles of the speech organs. To denote such movements which allow reflecting non-sound phenomena, S. V. Voronin introduced the notion of kineme [14, p. 71]. On the linguistic level, kinemes are approximated by the articulation of speech sounds to form articulatory imitatives.

The words imitating non-sound phenomena can designate the processes inside the human body or the events of the outer world. Thus, the second great division of the phonoiconic system is the distinction between the words belonging to intra- and extrasomatic domains.

The examples of intrasomatic designations are English cough, gnarl, gnaw, or sneeze.

The best-known examples of extrasomatic imitatives are the designations of round objects with labial sounds, such as English bulb, blob, or pumpkin.

2.1. Intrakinemes. The non-sound intrasomatic denotatum designates the processes taking place inside the human body [14, p. 74-76]. It includes reflective movements, such as swallowing, coughing, sneezing, sucking, etc., emotive movements, such as the mimics of disgust, laughing, smiling, etc. As far as these processes engage the movements of the speech apparatus (including facial muscles), such movements can serve as the basis for the imitative word coinage.

For example, the intrasomatic experience of pain involves a whole range of various reactions, one of which is the reaction of moaning, which involves the work of the speech apparatus and the nasal resonator as a part of a whole. Whining and howling are produced with almost closed lips, which puts to work the resonance of the nasal cavity. For this reason, the denotatum of moaning (and of all other processes metonymically connected with moaning) is the inner sensation connected with the activity of the nasal cavity. On the level of expressive gestures - intrakinemes - it will be a non-speech utterance produced with closed lips using the nasal resonator. On the linguistic level, this gesture will be approximated with nasal sonorants, with such resulting sound-imitative intrakinesemisms as English moan, pang, peenge, nag, etc. 
2.2. Extrakinemes. This type of denotatum denotes extrasomatic non-acoustic phenomena. In this case, the matching of an extralinguistic object and the denotatum is based on the similarity between a distinctive feature of the nominated object and a property of the articulatory movement. For example, the enlarged volume of the mouth cavity can be matched with rounded form or hollowness of the referent. On the level of the primary expressive gesture, this would be mimicked by puffing cheeks with closed lips. On the linguistic level, this gesture is approximated with labials, and the resulting sound-imitative forms include such extrakinesemisms as English pumpkin, balloon, ballot, belly, blub, boll, bowl, etc. As far as the extrasomatic experience can only be likened to its designation based on similarity, it is a metaphor.

\section{Phonosemantic interference.}

As I have shown in the previous part, there are three distinct categories of imitative words which correspond with three different mechanisms of motivation: 1 - onomatopoeia, 2 intrakinesemisms, and 3 - extrakinesemisms.

Voronin was the first to state that in some instances sound-imitative words and even whole phonosemantic groups demonstrate overlapping between the categories of acoustic and articulatory symbolism [14, p.74, 103-107; 29, p. 147-149]. The combination of motives was also mentioned by N. N. Gazov-Ginzberg [28, p. 47]. Recently this effect has been discussed by V. A. Ivanov, who posed a question about the nature of the interrelationship between onomatopoeia and sound symbolism [34]. N. N. Shvetsova has registered a mixed type of intraextrakinesemisms in her research, thus demonstrating the overlapping of the intra- and extrasomatic motivation [19]. The interplay between acoustic and non-acoustic symbolism is also discussed in the works by $[27,35,36]$.

According to the generally accepted approach in sound-imitative studies, the link between the sound-imitative form and its motive is understood as one-to-one mapping. Voronin challenged this approach in his book [14, p. 36] and formulated the universal phonosemantic law of multiple nomination (or many-to-many mapping). According to this law, one and the same object (denotatum) can be represented by several motives of nomination, as well as one and the same motive of nomination can represent several different objects (denotata) [14, p. 182-183]. What in fact Voronin stated by this law was the possibility of phonosemantic synonymy and homonymy. Nevertheless, the idea of many-to-many correlation can also apply to the combination of several denotata in a designation of one object.

After all these considerations I define the phenomenon in question in the following way: Phonosemantic interference is a phenomenon in which several nominating motives obtained through different modes of relation with reality combine to designate one sound-imitative sign. In the next part of the article I will provide the examples of the phonosemantic interference.

\section{Interference of motives in the imitative words of invented languages.}

1. Designations of blowing. This complex lexical-semantic group is one of the most obvious examples of interconnection between different types of motivation. Its specific features were discussed by S. V. Voronin, A. M. Gazov-Ginsberg, R. Paget [15; 3; 28, p. 31]. The motivating kineme of blowing belongs to the type of phono-intrakinesemisms. This type of sound-imitative words was especially singled out by S. V. Voronin as a type with multiple motivation: the main kinesic element (sound symbolism) is always accompanied by a secondary phonic element (onomatopoeia) [14, p. 90-93]. 
Blowing is an unvoiced expiratory process that occurs with protruded and rounded lips. The imitation of this movement lays the foundation for a vast semantic group of words whose meanings are connected with the idea of blowing. On the linguistic level, the main imitative element in various languages is represented by labial consonants and/or rounded vowels as an obligatory component [14, 37] - for example, English blow, hover, Latin sufflo, Latvian pūst, Turkish efil efil, Indones. pukulan.

Nevertheless, the phonosemantic analysis of this large lexical group reveals, that the basic labial component is often accompanied by secondary imitative elements, which clarify the semantics of the words. Take, for example, the English designations of wind. Acoustically, the sound of wind is a continual toneless noise (pure noise continuant in Voronin's classification). On the phonological level, the closest approximation of this type of sound is best achieved by voiceless fricatives [29, p. 64-65], normally in the auslaut position: puff, whuff, swuff, huff, whiff, swiff, fuff. Thus, this lexical group features the interplay of labials (sound symbolism) and voiceless fricatives (onomatopoeia).

At the same time, Voronin noticed, that, when the designations of blowing contain the semantics of an obstruction (for example, the idea of air explosion), their sound structure features obstruents in the anlaut position [15]. This results in such forms as puff, spuffle, buff, tuff, tiff, guff, guiff, blast, bamf. The articulatory component produces a palpable sensation of an air stream, and as such, it is a sympathetic imitation of a property of the extrasomatic denotatum (the blast of the air produced by the speech apparatus is similar/looks like a blast in the real world). Thus, we can register the interference between the intra- and extrasomatic motives of imitative word coinage. This interplay of motives allows mimicking the denotatum in a more precise manner.

My material contains several designations of blowing:

a) wind: $\operatorname{sul}$ [sul] 'wind' (Elvish); $S u S$ [sus] 'wind', 'breeze' (Klingon); hufwe [hu.' fwe] n. 'wind' (Na'vi).

Acoustically, the designations of the wind are continual toneless noises (pure noise continuants in Voronin's classification). On the phonological level, the closest approximation of this type of sound is best achieved by voiceless fricatives [29 p. 64-65]. Thus, this lexical group features the interplay of labials (sound symbolism) and voiceless fricatives (onomatopoeia) /s, s, $\mathrm{h} /$; the intrasomatic sensation of the airflow is rendered using the already mentioned fricatives and lateral $/ 1 /$.

Apart from its muscular performance, blowing has a cause-and-effect relationship with the sound produced, and the onomatopoeic component is not less tangible. This material demonstrates how different sound properties are rendered by onomatopoeic elements.

b) designation of whistling: fwefwi [' fwe.fwi] (Na'vi).

The denotatum of this word is a harsh and high tonal sound, which explains the use of high vowel /i/. Nevertheless, the articulatory gesture is even more expressive: the mimic connected with this sound form is self-explanatory and depicts the image of a whistling person. The fricatives rendering the intrasomatic sensation of the airflow are also in place. Thus, this is an example of triple phonosemantic interference: onomatopoeic, and, at the same time, sound symbolic in two aspects - in facial mimicking and articulation. 
Compare the designations of whistling in natural languages: English whiss, whistle, Finnish vihellys, Russian cвucm [svist], Latin sibilo, Indones. siul.

d) horn blowing: $h r u d u d u_{-}[$hrududu] 'tractor or any motor' (Lapine).

In this case, the sound of the word (onomatopoeic imitation) reflects the features of sound, such as pitch and volume, while the labial movement reflects the gesture of blowing. The reduplicated element $/-\mathrm{du} /$ in this example designates the low tone of a working motor engine.

e) swelling, roundness, expanding, and blooming: $p u b\left[\mathrm{p}^{\mathrm{h}} \mathrm{ub}\right]$ 'to boil' (Klingon); 'on [?on] 'form' (Na'vi); 'ong [?on] 'to unfold', 'to blossom' (Na'vi).

As different as they are, these examples share both the semantics of growth and unwinding of form, and the articulation with labial elements. The connection between the motives of blowing and expanding has been thoroughly discussed by A. B. Mikhalyov [38, p. 110]. Compare, for example, Turkish börtlemek 'to swell', 'to inflate', or bulk 'inflated'; the PIE roots *ball- *bhel- with a similar phonetic structure and the meanings 'to blow', 'to swell', 'to bloom', are the source for a large group of English words: bale, ball, balloon, balloon, ballot, belly, blain, bladder, blister, boast, boil, boll, bolster, bosom, bowl, bulk [25]. All these words are motivated by the articulatory gesture of blowing.

At the same time, it is a well-known fact that labials and rounded vowels are connected with the semantics of roundness and swelling [14; 39, p. 32-33; 28, p. 76-66]. This denotatum belongs to extrasomatic experience and has a different mode of form-sense mapping: with an external event, it is not felt as an inner muscular sensation, but rather likened to an articulatory movement of cheek puffing. Thus, we observe the interplay of intra- and extrasomatic motives expressed by different gestures - blowing and cheek puffing. The gesture of roundness and its resulting linguistic forms are extremely close to the designations of swelling both in form and meaning. Compare: English blob, bubble, bud, goggle, hump, or Turkish bulkak 'swelled'.

2. Designations of whining and howling. Acoustically, the act of whining or howling involves the production of durative tonal sounds, which are reflected in their speech designations with vowels (continuants in Voronin's classification) [14, p. 49]. High of low property of the tone is reflected by high or low vowels. This can be observed on the examples from natural languages: 1) sounds with high tone: English cheep, breet, bleep, squeal, Latin piparre 'to peep', Finnish sirkuttaa 'to twitter', Hung. csipog 'to cheep'; 2) sounds with low tone: English hoot, Russian yxamb [uxat'] 'to hoot', Spanish ululato 'howling'.

This is well demonstrated by the following examples, where high vowel $/ \mathrm{I} /$ is used for the designation of the high tone of whining, while the low tonal property of the $/ \mathrm{u} /$ vowel is used to designate a low tone of howling:

- vIng [vin] 'to whine' (Klingon);

- nguway ['yu.waj] 'to howl', 'viperwolf cry' (Na'vi);

- Huan [huan] 'great wolfhound' (Elvish);

- ngwaw [ywau] 'to howl' (Elvish).

At the same time, all the words in this semantic group contain labials or rounded vowels. I presume that this is an example of facial mimicking: the meaning of the words can be understood even without sound, only by looking at a person making the utterance.

Another interesting feature of his semantic group is the presence of the nasal sonorant $/ \mathrm{y} /$. In this case, the denotatum is the intrasomatic perception of the resonance, which is phonetically 
rendered by nasal sonorants to the same effect. S. V. Voronin notes that whining and howling is produced with almost closed lips, which puts to work resonance of the nasal cavity [14, p. 92]. Thus, we can observe the joint effect of onomatopoeia, extrasomatic and intrasomatic sound symbolism.

3. Designations of bowel sounds. There are several examples of words motivated by bowel sounds:

- bor [bor] 'to gurgle' (this specifically refers to the sound that a stomach makes) (Klingon);

- burgh [bury] 'stomach' (Klingon);

- chor [tor] 'belly' (Klingon);

- bur [bur] 'to hiccup' (Klingon).

Obviously, this group of words is onomatopoeic and designates the sounds of intestinal activity. Compare the natural onomatopoeic expressions with equal semantics: Russian бypyamb [burtfat'], English bowel rumble, growling stomach, gurgle, borborygmus.

As onomatopes, these words can be assigned to the class of frequentatives [29, p. 74-97], and as such, all of them contain vibrating $/ \mathrm{r} /$. The examples of onomatopes of turbulent water with vibrant $/ \mathrm{r} /$ in natural languages are abundant: English burble, ripple, Basque burburbur, Indones. cur, Bashkir šarlau, Turkish çur çur.

Another property of this group is the presence of labial consonants and rounded vowels. The labial component is quite often associated in the literature with roundedness, hollowness [Voronin, Slonitskaya], and, in particular, with belly and bowels: English belly, bottom, bladder, womb, German wanst 'abomasum', Russian брюхо [br'uxo] 'belly', and the PIE root *wed-er'belly', 'bowels', 'round', 'hollow'.

The combination of labial elements (sound symbolism) with onomatopoeic dissonance proves that this is another example of phonosemantic interference.

4. Designations of water noise.

- se'ayl [sc.' Pajl] 'tall, thin waterfall' (Na'vi);

- tseltsul [' 'tscl.tsul] 'whitewater rapids' (Na'vi).

These examples demonstrate phonetic forms motivated by the non-tonal continuous noise of a water stream. According to S.V.Voronin, it can be classified as a pure noise continuant [29, p. 59-67], which is rendered in the speech by fricative elements; in the above example the noise is realized by the fricative $/ \mathrm{s} /$ and the affricate $/ \mathrm{ts} /$. Apart from this onomatopoeic component, both words feature lateral sonorant $/ 1 /$, which has nothing to do with designations of noise but is well-known as a sound-symbolic element in designations of water and air movement for its "liquid nature" [29, p. 66].

The combination of onomatopoeia (fricatives) and sound symbolism (liquids) can be found in natural languages as well: Yakut. usun 'river stream', Ossetian sela 'waterfall', Vietnamese suối 'stream'.

\section{Designations of singing.}

- lawr [laur] 'melody' (Na'vi);

- rol [rol] 'to sing' (Na'vi).

The above examples demonstrate the combination of three motives of imitative word coinage. First, the lateral sonorant /1/, which is clearly associated with the fluency of voice flow during the process of singing. Compare the presence of this phoneme in the designations of 
singing from natural languages: lalala, tralala, y-лю-лю [u-l'u-l'u] [28, p. 48], Estonian laulma, English lilt. Second, the rounded /o/ and the diphthong /au/ employ the facial muscles connected with singing and allow mimicking the facial movements of a singing person. This allocates these words in the class of intrakinesemisms. And, finally, the vibrant $/ \mathrm{r} /$ supposedly performs here the onomatopoeic function of voice trembling (a frequentative in Voronin's classification). The form of the word rol is especially self-explanatory: even its voiceless articulation creates an image of a singing person. This is the case of the combination of onomatopoeia, articulatory sound symbolism, and facial mimicking.

\section{Designations of swallowing.}

Two artificial languages - Klingon and Navi - have a whole group of words motivated by the physiological act of swallowing, including the meanings 'throat', 'gargle', 'food', 'hungry', etc. The denotatum is the muscular sensation connected with the act. This kineme is realized by the articulations which employ the muscles of the throat: the velar consonants $/ \mathrm{k}^{\prime} /, / \gamma /, / \mathrm{x} /$, glottal /h/, / /, and low back vowels /u/, and /a/:

- kxukx [k'uk'] 'to swallow' (v) (Na'vi);

- ghup [rup'] 'to swallow' (Klingon);

- Hugh [xuy] 'throat' (Klingon);

- ohakx - [o. 'hak'] 'hungry' (Na'vi);

- ghagh [yay] 'to gargle' (Klingon);

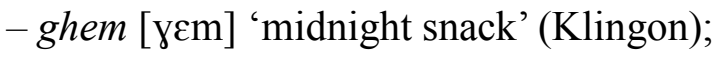

- megh [mey] 'lunch' (Klingon).

All of these examples belong to the class of guttural intrakinesemisms. Compare natural examples of swallowing with similar phonosemantic structure: English glug, gobble, gullet, gulp, guzzle, chugalug, Indones. meneguk' gulp'.

Among these, the Klingon word ghagh 'to gargle' is the example of phonosemantic interference, as it demonstrates the properties of an onomatope: the velar fricative $/ \mathrm{\gamma} /$ and the vibrant $/ \mathrm{r} /$ render a clear image of pure noise and vibration produced by water in the throat.

The examples of ghem and megh are also of interest. The bilabial $/ \mathrm{m} /$, presumably, is a mimicking component, which employs facial muscles and can be found in the designation of eating, such as English yum, omnomnom, German mjam mjam, etc. Thus, this can be a combination of intrasomatic and facial mimicking denotata.

Results and discussion. The phonosemantic analysis of the artificially constructed lexicons by the method developed by S. V. Voronin has revealed that they contain sound-imitative words, and a number of these words can be arranged in phonosemantic groups motivated by several motives of nomination. The interfering motives belonging to different types of denotata produce different combinations: (1) onomatopoeia and sound symbolism; (2) in the area of sound symbolism, the combination of intra- and extrasomatic motives; (3) in the area of intrasomatic denotatum, the combination of facial mimicks and articulatory movements. The latter combination has never been mentioned before.

The comparative analysis performed against the imitative lexis of natural languages has revealed similar models of motivation, including the instances of multiple motivation. This suggests that this is a regular type of word coinage rather than a random occurrence. 
Multiple motivation reflects the complex nature of the perception of extralinguistic objects. The psycho-physiological image of such an object is always intersensorial and intermodal, even in the event of sound-to-sound imitation. In the case of phonosemantic interference, the phonetic form of a word is the product of a co-operative action of several senses.

Concerning the function of the phonosemantic interference, it is obvious that the combination of several denotata for one linguistic sign amplifies the basic structure and thus increases the variety of primary forms and meanings. With the help of the phonosemantic analysis of large semantic groups (i. e. denotations of blowing) it is possible to reveal a general formal structure and its complicated variations. This sophistication of form helps explicate subtle semantic contrasts, for example, distinguish between blowing and inflating, or between blowing with tonal and non-tonal sound, etc.

Conclusion. The study of motivation in the area of the sound-imitative system of language is a difficult task due to the diachronic loss of the primary form and meaning in the natural sound-imitative lexis. To overcome this difficulty, artificially constructed lexicons of invented languages were selected as the material for the study. The unchanged primary forms and hypervariability make this type of material a useful object of phonosemantic studies.

The similarity of motivational pattern found in the course of comparative analysis both in natural and artificial lexis suggests a universal nature of multiple sound-imitative nomination.

The notion of phonosemantic interference defined in the present paper enables analyzing, describing, and understanding the mechanisms of complicated cases of imitative word coinage within the framework of the already well established phonosemantic taxonomy.

\section{REFERENCES}

1. Jespersen, O. (1922), "Symbolic value of the vowel I", Philologica, no. 1, pp. 15-33.

2. Sapir, E. (1929), "A Study in Phonetic Symbolism", Journal of Experimental Psychology, vol. 3, no. 12, pp. 225-239. DOI: https://doi.org/10.1037/h0070931.

3. Paget, R. (1930), Human Speech (Some Observations, Experiments, and Conclusions as to the Nature, Origin, Purpose and Possible Improvement of Human Speech), Routledge and Kegan Paul Ltd., London, UK.

4. Hockett, C.F. (1960), "The origin of speech", Scientific American, vol. 203, pp. 88-96.

5. Bolinger, D.L. (1962), "Intonation as a universal", Proceedings of the Ninth International Congress of Linguistics, in Lunt, H.G. (ed.), Mouton, The Hague, FRA, pp. 833-844.

6. Bolinger, D.L. (1978), "Intonation across languages", Universals of Human Language, vol 2: Phonology, in Greenburg, J.H., Ferguson, C.A., and Moravcsik, E.A. (eds.), Stanford Univ. Press, Stanford, USA, pp. 471-524.

7. Ohala, J.J. (1983), "Cross-language use of pitch: an ethological view", Phonetica, vol. 40, no. 1, pp. 1-18. DOI: 10.1159/000261678.

8. Ohala, J.J. (1994), "The frequency code underlies the sound symbolic use of voice pitch", Sound Symbolism, in Hinton, L., Nichols, J. and Ohala, J.J. (eds.), Cambridge Univ. Press, Cambridge, UK, pp. 325-347.

9. Traunmüller, H. (1994), "Sound symbolism in deictic words", Tongues and Texts Unlimited. Studies in Honour of Tore Jansson on the Occasion of his Sixtieth Anniversary, in Auli, H., and Trampe, P. (eds.), Dept. of Classical Languages, Stockholm Univ., SWE, pp. 213-234.

10. Ramachandran, V.S. and Hubbard, E.M. (2001), "Synaesthesia - A window into perception, thought and language", Journal of Consciousness Studies, vol. 8, no. 12, pp. 3-34. 
11. Nobile, L. (2011), "Words in the mirror. Analysing the sensorimotor interface between phonetics and semantics in Italian", Semblance and Signification, in Michelucci, P., Fisher, O., and Ljungberg, Ch. (eds.), John Benjamins Publ. Company, Amsterdam/Philadelphia, pp. 101-132.

12. Johansson, N. and Zlatev J. (2013), "Motivations for Sound Symbolism in Spatial Deixis: A Typological Study of 101 Languages", The Public Journal of Semiotics, vol. 5, no. 1, pp. 3-20.

13. Bankieris, K. and Simner, J. (2015), "What is the link between synaesthesia and sound symbolism?", Cognition, vol. 136, pp. 186-195. DOI: https://doi.org/10.1016/j.cognition.2014.11.013.

14. Voronin, S.V. (2006), Osnovy fonosemantiki [The Fundamentals of Phonosemantics], Lenand, Moscow, RUS.

15. Voronin, S.V. (1975), "Angliiskie zvukoizobrazheniya dunoveniya rtom [English sound imitatives of blowing]", Voprosy leksikologii, leksikografii i stilistiki. Trudy Samarkandskogo gosudarstvennogo universiteta imeni A. Navoi, vol. 291, Samarkand, pp. 48-51.

16. Flaksman, M.A. (2015), "Diachronic development of English iconic vocabulary", Can. Sci. (Ling.) Thesis, St Petersburg State Univ., SPb., RUS.

17. Davydova, V.A. (2016), "Sound Symbolism in Invented Languages", in Flaksman, M.A., Brodovich, O.I. (eds.), Anglistics of the XXI century, vol. 2. Phonosemantics: in commemoration of Professor Dr. Stanislav Voronin's 80th anniversary, St Petersburg State Univ., SPb., RUS, pp. 32-39.

18. Davydova, V.A. (2017), "Lingvokonstruirovanie i materija zvuka: fenomen onomatopei v vymyshlennyh jazykah (Word coinage and sound: onomatopoeia in invented languages)", Current Issues of Linguistics, VI international scientific and practical conference, SPb., ETU, RUS, 20 apr. 2017, pp. 266-273.

19. Shvetsova, N.N. (2011), "Iconic Words in English Dialects", Can. Sci. (Ling.) Thesis, St Petersburg Univ. of Economy, SPb., RUS.

20. Adams, R. (2005), Watership Down: A Novel, Scribner, N.Y., USA.

21. Okrand, M. (1992), The Klingon Dictionary, 2nd ed., Pocket Books, N.Y., USA.

22. Fauskanger, H.K. (2013), Quettaparma Quenyallo / Quenya-English Wordlist, available at: https://folk.uib.no/hnohf/wordlists.htm (accessed 17.06.2020).

23. Miller, M. (2019), Na'vi-English Dictionary v. 14.2, available at: https://eanaeltu.learnnavi.org/ dicts/NaviDictionary.pdf (accessed 17.06.2020).

24. Voronin, S.V. (1990), "O metode fonosemanticheskogo analiza [On the method of phonosemantic analysis]", Lingvometodicheskie Aspekty Semantiki I Pragmatiki Teksta, Kursk, USSR, pp. 98-100.

25. Flaksman, M.A. (2016), Slovar' angliiskoi zvukoizobrazitel'noi leksiki v diakhronicheskom osveshchenii [Dictionary of English sound-visual vocabulary in diachronic lighting], Institute of Foreign Languages, RKhGA, SPb., RUS.

26. Serebrennikov, B.A. (1977), Yazykovaya nominatsiya: obshchie voprosy [Language nomination: general issues], Nauka, Moscow, USSR.

27. Davydova, V.A. (2019), "Zhestovaia motivatsiia zvukoizobrazitelnyx slov: litsevaya mimika v zvukoizobrazheniiax malogo razmera (The Gestural Motivation for Sound-Symbolic Words: Facial Mimics in Denominations of Smallness)", Current Issues of Linguistics, VIII international scientific and practical conference, SPb., ETU, RUS, 22-23 apr. 2019, pp. 243-249.

28. Gazov-Ginzberg, A.M. (1965), Byl li yazyk izobrazitelen v svoikh istokakh? (Svidetel'stvo prasemitskogo zapasa kornei) [Was the language pictorial in its origins? (Evidence of a presemite stock of roots)], Nauka, Moscow, USSR.

29. Voronin, S.V. (2004), Angliiskie onomatopy: fonosemanticheskaya klassifikatsiya [English Onomatopes: a Phonosemantic Classification], Gelikon Plyus, SPb., RUS.

30. Voronin, S.V. (2005), Iconicity. Glottogenesis. Semiosis: Sundry Papers, St Petersburg Univ. Press, SPb., RUS.

31. Galeev, B.M. (1987), Chelovek, iskusstvo, tekhnika (problemy sinestezii v iskusstve) [Man, art, technology (problems of synesthesia in art)], Kazan, Izd-vo KGU, USSR. 
32. Gorelov, I.N. (1977), "The problem of the Functional Basis of Speech]", Dr. Sci. (Philol.) Thesis, Magnitogorsk Pedagogical Institute, Magnitogorsk, USSR.

33. Leont'ev, A.N. (1983), Izbrannye psikhologicheskie proizvedeniya [Collected Works in Psychology], vol. II, Pedagogika, Moscow, USSR.

34. Ivanov, V.A. (2017), "Onomatopoeic designations of knocks in Finno-Ugric and Turkic languages", Current Issues of Linguistics, VI international scientific and practical conference, SPb., ETU, RUS, 20 apr. 2017, pp. 274-280.

35. Koleva-Zlateva, Zh. (2009), "On the coalescence of homonymic etymological nests of sound symbolic origin], Slavica, XXXVIII, pp. 19-34.

36. Jääskeläinen, A. (2016), "Mimetic schemas and shared perception through imitatives", Nordic Journal of Linguistics, vol. 39, no. 2, pp.159-183. DOI: https://doi.org/10.1017/S0332586516000147.

37. Mazanaev, I.A. (1985), "The Main Groups of English and Lesgin Iconic Words", Can. Sci. (Philol.) Thesis, Univ. of Leningrad, Leningrad, USSR.

38. Mikhalev, A.B. (1995), Teoriya fonosemanticheskogo polya [The Theory of the Phonosemantic Field], Izd-vo Pyatigor. gos. lingv. un-ta, Krasnodar, USSR.

39 Slonitskaya, E.I. (1987), "Sound-Symbolism in Designating Roundedness", Can. Sci. (Philol.) Thesis, Univ. of Leningrad, Leningrad, USSR.

\section{Information about the author.}

Varvara A. Davydova - Assistant Professor at the the Department of Foreign Languages, Saint Petersburg Electrotechnical University, 5 Professor Popov str., St Petersburg 197376, Russia. The author of 11 scientific publications. Area of expertise: iconicity, invented languages, phonosemantics. ORCID: https://orcid.org/0000-0002-4475-5267. E-mail: va.davydova@gmail.com

\section{СПИСОК ЛИТЕРАТУРЫ}

1. Jespersen O. Symbolic value of the vowel i // Philologica. 1922. No. 1. P. 15-33.

2. Sapir E. A Study in Phonetic Symbolism // Journal of Experimental Psychology. 1929. Vol. 3, iss. 12. P. 225-239. DOI: https://doi.org/10.1037/h0070931.

3. Paget R. Human Speech (Some Observations, Experiments, and Conclusions as to the Nature, Origin, Purpose and Possible Improvement of Human Speech). London: Routledge and Kegan Paul Ltd., 1930.

4. Hockett C. F. The origin of speech // Scientific American. 1960. Vol. 203. P. 88-96.

5. Bolinger D. L. Intonation as a universal // Proceed. of the Ninth International Congress of Linguistics / ed. by H. G. Lunt. The Hague: Mouton, 1962. P. 833-844.

6. Bolinger D. L. Intonation across languages // Universals of Human Language. Vol 2: Phonology / in J. H. Greenburg, C. A. Ferguson, E. A. Moravcsik (eds.). Stanford: Stanford Univ. Press, 1978. P. 471-524.

7. Ohala J. J. Cross-language use of pitch: an ethological view // Phonetica. 1983. Vol. 40, iss. 1. P. 1-18. DOI: 10.1159/000261678.

8. Ohala J. J. The frequency code underlies the sound symbolic use of voice pitch // Sound Symbolism / in L. Hinton, J. Nichols, and J. J. Ohala (eds.). Cambridge: Cambridge Univ. Press, 1994. P. 325-347.

9. Traunmüller H. Sound symbolism in deictic words // Tongues and Texts Unlimited. Studies in Honour of Tore Jansson on the Occasion of his Sixtieth Anniversary / in H. Auli, and P. Trampe (eds.). Dept. of Classical Languages, Stockholm Univ., 1994. P. 213-234.

10. Ramachandran V. S., Hubbard E. M. Synaesthesia - A window into perception, thought and language // Journal of Consciousness Studies. 2001. Vol. 8, iss. 12. P. 3-34. 
11. Nobile L. Words in the mirror. Analysing the sensorimotor interface between phonetics and semantics in Italian // Semblance and Signification / in Michelucci, P., Fisher, O., and Ljungberg, Ch. (eds.). Amsterdam/Philadelphia: John Benjamins Publ. Company, 2011. P. 101-132.

12. Johansson N., Zlatev J. Motivations for Sound Symbolism in Spatial Deixis: A Typological Study of 101 Languages // The Public Journal of Semiotics. 2013. Vol. 5, iss. 1. P. 3-20.

13. Bankieris K, Simner J. What is the link between synaesthesia and sound symbolism? // Cognition. 2015. Vol. 136. P. 186-195. DOI: https://doi.org/10.1016/j.cognition.2014.11.013.

14. Воронин С. В. Основы фоносемантики. М.: Ленанд, 2006.

15. Воронин С. В. Английские звукоизображения дуновения ртом // Вопр. лексикологии, лексикографии и стилистики / Тр. Самаркандского гос. ун-та / отв. ред. Л. К. Жукова. Самарканд, 1975. Вып. 291. С. 48-51.

16. Флаксман М. А. Диахроническое развитие звукоизобразительной лексики английского языка: дис. ... канд. филол. наук / СПбГУ. СПб., 2015.

17. Davydova V. A. Sound Symbolism in Invented Languages // Anglistics of the XXI century. Vol. 2. Phonosemantics: in commemoration of Professor Dr. Stanislav Voronin's $80^{\text {th }}$ anniversary; in by M. A. Flaksman, O. I. Brodovich (eds.). SPb.: St Petersburg State Univ., 2016. P. 32-39.

18. Давыдова В. А. Лингвоконструирование и материя звука: феномен ономатопеи в вымышленных языках // Актуальные проблемы языкознания: мат. VI междунар. науч.-практ. конф. Санкт-Петербург, 20 апр. 2017 г. / СПбГЭТУ «ЛЭТИ». СПб., 2017. С. 266-273.

19. Швецова Н. Н. Звукоизобразительная лексика в английских диалектах: дис. ... канд. филол. наук / СПбГУ. СПб., 2011.

20. Adams R. Watership Down: A Novel, N.Y.: Scribner, 2005.

21. Okrand M. The Klingon Dictionary / 2nd ed. N.Y.: Pocket Books, 1992.

22. Fauskanger H. K. Quettaparma Quenyallo / Quenya-English Wordlist. 2013. URL: https://folk.uib.no/hnohf/wordlists.htm (дата обращения: 17.06.2020).

23. Miller M. Na'vi-English Dictionary v. 14.2. 2019. URL: https://eanaeltu.learnnavi.org/dicts/ NaviDictionary.pdf (дата обращения: 17.06.2020).

24. Воронин С. В. О методе фоносемантического анализа // Лингвометодические аспекты семантики и прагматики текста. Курск, 1990. С. 98-100.

25. Флаксман М. А. Словарь английской звукоизобразительной лексики в диахроническом освещении / Ин-т иностранных языков. СПб., РХГА, 2016.

26. Серебренников Б. А. Языковая номинация: общие вопросы. М.: Наука, 1977.

27. Давыдова В. А. Жестовая мотивация звукоизобразительных слов: лицевая мимика в звукоизображениях малого размера // Актуальные проблемы языкознания: мат. VIII междунар. науч.-практ. конф. Санкт-Петербург, 22-23 апр. 2019 г. / СПбГЭТУ «ЛЭТИ». СПб., 2019. С. 243-249.

28. Газов-Гинзберг А. М. Был ли язык изобразителен в своих истоках? (Свидетельство прасемитского запаса корней). М.: Наука, 1965.

29. Воронин С. В. Английские ономатопы: фоносемантическая классификация. СПб.: Геликон Плюс, 2004.

30. Voronin S. V. Iconicity. Glottogenesis. Semiosis: Sundry Papers. SPb.: St Petersburg Univ. Press, 2005.

31. Галеев Б. М. Человек, искусство, техника (проблемы синестезии в искусстве). Казань: Изд-во КГУ, 1987.

32. Горелов И. Н. Проблема функционального базиса речи: дис. ... д-ра филол. наук / МПИ. Магнитогорск, 1977.

33. Леонтьев А. Н. Избранные психологические произведения. Т. ІІ. М.: Педагогика, 1983.

34. Иванов В. А. Звукоизображения ударов в финно-угорских и тюркских языках // Актуальные проблемы языкознания: мат. VI междунар. науч.-практ. конф. Санкт-Петербург, 20 апр. 2017 г. / СПбГЭТУ «ЛЭТИ». СПб., 2017. С. 274-280. 
35. Колева-Златева Ж. О смешивании этимологических гнезд омонимичных слов звукоизобразительного происхождения // Slavica (Debrecen). 2009. XXXVIII. C. 19-34.

36. Jääskeläinen A. Mimetic schemas and shared perception through imitatives // Nordic Journal of Linguistics. 2016. Vol. 39, iss. 2. P. 159-183. DOI: https://doi.org/10.1017/S0332586516000147.

37. Мазанаев И. А. Основные группы звукосимволических слов: фоносемантический анализ: на материале англ. и лезг. яз.: дис. ... канд. филол. наук / ЛгУ. Л., 1985.

38. Михалев А. Б. Теория фоносемантического поля. Краснодар: Изд-во Пятигор. гос. лингв. ун-та, 1995.

39. Слоницкая Е. И. Звукосимволизм обозначений округлого (опыт типол. исслед): дис. ... канд. филол. наук / ЛГУ. Л., 1987.

Информация об авторе.

Давыдова Варвара Алексеевна - ассистент кафедры иностранных языков СанктПетербургского государственного электротехнического университета «ЛЭТИ» им. В. И. Ульянова (Ленина), ул. Профессора Попова, д. 5, Санкт-Петербург, 197376, Россия. Автор 11 научных публикаций. Сфера научных интересов: звукоизобразительность, вымышленные языки, фоносемантика. ORCID: https://orcid.org/0000-0002-4475-5267. E-mail: va.davydova@gmail.com 